\title{
Porto Alegre, Paris ve Seul Katılımcı Bütçe Modelleri
}

\section{Porto Alegre, Paris and Seul Participatory Budgeting Models}

\author{
Dr. Öğr. Üyesi İsmail GÜNEŞĐ1
}

\begin{abstract}
$\ddot{\mathbf{O} z}$
Bundan 30 yıl önce Brezilya'nın Porto Alegre 'de başlayan katılımcı bütçeleme demokratik bir süreçtir ve vatandaşlar doğrudan bir kamu bütçesinin belirli bir bölümünün tahsisine katılmaktadırlar. Katılımcı Bütçeleme vatandaşlara yatırım teklifleri sunma ve ardından açık oylama yoluyla hangi projelerin finanse edilmesi ve uygulanması gerektiğini seçmelerini sağlar. Uygulamada tek bir katılımcı bütçe modelinden bahsetme olanağına sahip değiliz. Her ülkenin kendi özgün koşullarından hareketle farklı modeller geliştirmeye çalıştıkları görülmektedir. Bu çalışmada uygulamanın ilk ortaya çıktığı Porto Alegre modeli yanı sıra büyük ölçekli kentlerden Seul ve Paris’te katılımcı bütçeleme örnekleri analiz edilecektir. Seul, 10 milyonu aşan nüfusu ile daha çok küçük ölçekli yerlerde başarılı örneklerini gördüğ̈̈müz katılımcı bütçe uygulamalarının büyük bir ölçekte nasıl işleyeceğini göstermesi açısından incelenmesi gereken bir kenttir.
\end{abstract}

Anahtar Kelimeler: Katılımcı demokrasi, katılımcı bütçeleme, Paris, Seul, Porto Alegre, yönetişim

Makale Türü: Araştırma

\begin{abstract}
Participatory budgeting is a democratic process which began in Porto Alegre one of the most populous cities in Brazil 30 years ago and citizens are directly involved in the allocation for a part of a public budget. Participatory Budgeting allows citizens to choose which projects should be financed and implemented by submitting investment proposals by open voting. We do not have an opportunity to mention a single participant budget model in practice. It has been seen that each country tries to develop different models based on its own unique conditions. The Porto Alegre model which the application first emerged as well as the participatory budgeting examples in the major cities of Seoul and Paris will be analyzed in this study. Seoul is a city with a population exceeding 10 million should be examined in terms of how the participatory budgeting practices would work on a large scale which we have seen many successful examples more in smaller-scale places.
\end{abstract}

Keywords: Participatory democracy, participatory budgeting, Paris, Seoul, Porto Alegre, governance

Paper Type: Research

${ }^{1}$ Çukurova Üniversitesi, IIIBF, ismailgunes@cu.edu.tr.

Atıf için (to cite): Güneş, İ. (2020). Porto Alegre, Paris ve Seul katılımcı bütçe modelleri. Afyon Kocatepe Üniversitesi Sosyal Bilimler Dergisi, 22(2), 537-554. 


\section{Giriş}

Katılımcı bütçe, vatandaşların yerel kamu politikalarına ve özellikle de kurumun bütçesine katılımını teşvik eden bir yöntemdir. Önceden ana teması belirlenmiş alanlarda yapılacak harcamaların hangi yatırımlara yapılacağına karar veren demokratik bir araçtır. Brezilya' da uzun yıllar devam eden askeri diktatörlük dönemi sonrasında ilk kez Porto Alegre'de uygulanmıştır. Kısa sürede Brezilya'nın diğer kentlerine ve komşu ülkelere yayılan katılımcı bütçe uygulamaları, Dünya Sosyal Forumu'ndan sonra yayılmaya başlamış, Avrupa'yı ve Uluslararası kuruluşları da etkisi altına almayı başarmıştır.

Kamu maliyesi açısından bakıldığında ise son yıllarda heyecan yaratan gelişmelerin başında katılımcı bütçe gelmektedir. Katılımcı bütçe, vatandaş ve kamu kuruluşları arasında güçlü bağlantılar kurulmasına ve iş birliklerine neden olmuştur. Vatandaş ile devlet arasındaki mali bağlantının zayıfladığı dönemlerde vatandaşın kalbine dokunan bir uygulama olarak hızla yayılmıştır. Katılımcı bütçeleme özellikle son yıllarda temsili demokrasiye yöneltilen eleştiriler karşısında katılımcı ve doğrudan demokrasinin pratik bir örneği olmuştur. Katılımc1 bütçe sayesinde, vatandaşlarla yerel yönetişim arasında doğrudan bir ilişki kurmak, insanları ve seçmenleri siyasete ve bölge yönetimine yakınlaştırmak mümkün olmuştur.

Çalışmamızda, katılımcı bütçenin doğduğu Porto Alegre örneği, öncelikli olarak ele alınmıştır. Porto Alegre, diğer ülke uygulamalarına esin kaynağı olmuştur. Zaman içinde katılımcı bütçe uygulamaları artmıştır. Farklı ülke uygulamaları yer yer benzerlikler göstermelerine rağmen tek bir katılımcı bütçe modelinden bahsedemeyiz. Ülkeler kendi sosyal, ekonomik, kültürel yapılarına uygun model arayışlarını sürdürmektedir. Bu anlamda çalışmamızda seçilen diğer kentlerden Seul, 10 milyonu aşan nüfusu ile daha çok küçük ölçekli yerlerde başarılı örneklerini gördüğümüz katılımcı bütçe uygulamalarının büyük bir ölçekte nasıl işleyeceğini göstermesini açısından dikkatle incelenmesi gereken bir kenttir. Aynı şekilde sivil toplulukların ekonomik, sosyal ve politik olarak aktif katılım gösterdiği Paris kenti uygulaması, tüm dünyanın yakından takip ettiği örneklerin başında gelmektedir. Çalışmamızda seçilen örnekler ve uygulanan modeller tanıtılarak başta Türkiye olmak üzere büyük ölçekli kentlere sahip ülkelerde benzer uygulamalar için bilgi sunmayı amaçlamaktadır.

\section{Katılımcı Bütçe Nedir?}

Katılımcı Bütçeleme belirli bir coğrafi alandaki topluluk üyelerinin bütçenin belirli bir kısmını önerdikleri projeler aracılığı ile harcamak için karar verdikleri katılımcı ve demokratik bir süreci ifade etmektedir. Bazıları bu durumu "demokrasinin demokratikleştirilmesi" diye de ifade etmektedir. Katılımcı bütçe konusunda yapılan farklı tanımlar kavram üzerinde bir uzlaşma olmamasından daha çok, oldukça geniş ve farklı yönleriyle ele alınabilecek olan konuya farklı yaklaşımlardan kaynaklanmaktadır (Tekeli 2004,2).

Goldfrank, katılım bütçeye ayrı bir anlam katarak yönetim erkini elinde tutan ve bütçe yapma yetkisine sahip olanların almış oldukları bütçe kararının bir kısmının vatandaşlar, gönüllüler, sivil toplum kuruluşları gibi dinamikler eliyle yenilenmesi ve gözden geçirilmesi olarak ifade etmektedir (Goldfrank, 2006, s. 1-2). Mitchell ise, konuya daha çok bir danışma, halkın görüş ve isteklerine kulak verme ve ortaklık ruhunun güçlendirilmesi, yenilikçi müzakereci yöntemle daha proaktif ve daha şeffaf bir bütçe sürecine izin verilmesi olarak tanımlamaktadır (Mitchell, 2014, s. 5).

Wampler ise, Katılımcı bütçe yöntemini oldukça yenilikçi bir politik işlem olarak görmektedir. Vatandaşlar siyasi kararlara doğrudan katılmak suretiyle kaynak tahsisatı sürecini etkilemekte ve sosyal politikalara öncelik vermektedirler. Bu ise kamu harcamalarının yapısını etkilemektedir (Wampler, 2000, 2). Marquetti, Silva ve Campbell (2012), katılımcı bütçelemeyi, yerel toplulukların kaynakların nasıl ve nerede kullanıldığının belirlenmesinde, vatandaşların ve sivil toplum kuruluşlarının doğrudan katılma hakkına sahip olduğu, katılımcı bir demokrasi olarak tanımlamaktadır (Marquetti, Silva, Campbell, 2012, s. 63). 
Dünya Bankası ise Katılımcı Bütçelemeyi güçlü bir belediye başkanı desteği ile gönüllü katılım gösterme arzusu olan Sivil Toplum Kuruluşlarının katılımıyla, finansal kaynakların vatandaşlar tarafından seçilen projelere harcandığı bir yöntem olarak tanımlamaktadır ve vatandaşları, kamu bütçelemesi karar verme sürecine dâhil etmeyi amaçlayan yenilikçi bir mekanizma olarak ifade etmektedir (Sahah, 2007). Birleşmiş Milletler İnsan Yerleşimleri Programı ise katılımcı bütçeyi; halkın, kullanılabilir kamu kaynaklarının tamamı veya bir kısmı ile ilgili karar verdiği veya verilecek kararlara katkıda bulunduğu mekanizma veya süreç olarak tanımlamaktadır (UN-Habitat, 2004, 20).

Genel anlamda, katılımcı bütçe, insanların yaşadıkları yerleşim yerlerinde sunulacak hizmetler ilgili karar vermesi veya karar verilmesine katkıda bulunmasına katkı yaptığı süreçtir. Katılımcı bütçeleme kolektif karar alma, siyasal katılım, yönetişim, davranış ekonomisi, oyun teorisi gibi alanlar ile ilişkilendirilerek de ele alınabilir. Konuya mali yaklaşım çerçevesinde yaklaştığımızda konunun özünde kamusal kaynakların nasıl kullanılacağ almak vardır. Bu kaynaklar özünde halkındır ve seçilmiş temsilciler aracılığı ile tekrar onlar için kullanılmaktadır. Modern kamu maliyesi ve bütçe bu anlamda üç ana hedefe odaklanır. Bunlar; kaynak dağılımında etkinlik, gelir dağılımında adalet ve ekonomik istikrarın sağlanmasıdır. Katılımcı bütçeye yaklaşım tarzımızın temelini bu üç ana fonksiyon oluşturmaktadır. $\mathrm{Bu}$ çerçevede tanımlamamız gerekirse katılımcı bütçeleme; bütçe karar alma mekanizmasına halkın ve STK'nın katılımını sağlamak suretiyle bütçe kaynaklarının toplumsal kesimler arasında tahsisatını sağlayan, uygulama sonuçları ile gelir dağılımı iyileştirmeyi hedefleyen, ekonomik istikrara katkı sağlayacak demokratik ve katılımcı bir yöntemdir.

\section{Katılımcı Bütçenin Tarihsel Gelişimi}

"Mutlu Liman" anlamına gelen Porto Alegre Brezilya'nın Güneyinde Rio Grande do Sul eyaletinin başkentidir.1772 yılında Portekiz'in Asor Adaları'ndan gelen göçmenlerce kurulmuştur. 19. yy sonlarında başta Almanya, İtalya ve Polonya olmak üzere Avrupa'nın birçok yerinden göçmen buraya gelmiştir. Bu nedenle nüfusunun tamamına yakını Avrupa kökenli olması ile dikkatleri çeker. Bu kent 1989 yılında katılımcı bütçeleme uygulaması ile tüm dünyanın ilgi odağı olmuştur (Çelebi, 2012).

Katılımcı bütçe fikrinin öncelikle Porto Alegre'de oluşmasını sağlayan öncülleri göz ardı ederek bu oluşumu anlamak mümkün değildir. Her şeyden önce Porto Alegre'de sivil toplum kuruluşları, sendika veya mahalle örgütlenmesi geleneği 1950'li yıllara uzanır. Köklü bir geleneği vardır. Porto Alegre'nin Avrupalı göçmenlerden oluşması nedeniyle eğitim düzeyi yüksektir ve Brezilya için tarihsel süreçte ciddi insani bir sorun olan kölelik uygulamaları azdır. Bu tarihsel süreçte kentte daha aydın bir kitle oluşumuna katkı yapmıştır. Büyük toprak sahipliği yerine küçük mülkiyetin ve görece daha eşitlikçi bir sosyal yapının mevcudiyeti üretim ve tüketim ilişkilerini belirlemiştir. Diktatörlüğe karşı toplumsal muhalefet geleneği bulunmaktadır. Brezilya'da gelir eşitsizlikleri ve yoksulluk sıradan bir görüntüdür. Özellikle politik yozlaşma örnekleri çok sayıda görülmektedir. Yerel düzeyde yolsuzluk ve adam kayırmacılık yaygındır. Seçimlerde oyların satın alınması sıklıkla görülen durumlardandır. Anayasal olarak garanti edilen haklar gerçekte işletilmemektedir. Porto Alegre bu gelenekten biraz ayrışmaktadır (Sakınç ve Bursalığlu, 2014, s. 6).

1970'ten önce Brezilya'nın genel görünümü, zayıf bir kamusal alan, seçkinci siyasi partiler ve otoriter bir ülke şeklindedir. 1988 sonrası ülke çapında yerel katılımcı kurumların yükselmesine ve başarısına izin veren bir yapı ortaya çıkmıştır. Brezilya'daki katılımcı bütçe alanındaki gelişmeleri sadece Porto Alegre örneğine dayandırmak eksik bir analiz olacaktır. Bu süreci hızlandıran etmenlerin en önemlisi Brezilya' da yapılan anayasal düzenlenmeler olmuştur.

1988 yılında kabul edilen Brezilya Anayasası, ülkedeki demokratikleşmenin önünü açmış, yerel yönetimlerin özerkliği ve gelişimi açısından bir dönüm noktası olmuştur. 1988 Anayasası ile eyaletlere ve yerel yönetimlere çok geniş bir özerklik tanınmıştır. Yerel yönetimlerin kamu gelirlerinden aldıkları paylarda artışlar olmuştur. Brezilya'da, çoğu federatif 
yapının aksine, yerel yönetimler eyaletlerin parçası değildir.1988 Anayasası'nın 29. maddesinde, her bir belediyenin kendi faaliyetleri ile ilgili düzenleme yapması ve meclislerinde kabul etmesi öngörülmektedir. Buna göre, belediyeler iki oturum arasında en az on günlük bir ara bulunan iki aşamalı meclis çalışmasıyla belediye meclisi üyelerinin en az üçte ikisinin çoğunluğu ile kabul edilen bir "organik yasa" ile yönetilmektedir (Sobacı ve Köseoğlu 2016, s. 36-37).

Brezilya'da üç ana boyutta değişim gerçekleştirilmiştir. Bunlar; sivil toplum, siyasal yapı ve kurumsal tasarımdır. Hangisinin daha ağırlıklı veya öncül olduğu araştırmamızın konusu değildir. Ancak demokratik ve katılımcı anlayışın egemen kılınması, kurumların bu anlayışa göre yeniden düzenlenmesi, sivil toplumun katılımcı olması sonucunda Porto Alegre ile başlayan hareket kısa zamanda ekonomik ve siyasal sistemi farklı ülkelerde bile karşıllık bulmuştur.

1964-1985 döneminde 20 yılı aşkın süre Brezilya, diktatörler tarafından yönetilmiştir. 1998 yılına gelindiğinde Brezilya sivil toplumun daha özgürce işlev görmesini sağlayan demokratik bir anayasaya sahipti. Brezilya, orta gelirli ülkeler arasında en fazla yoksulu olan ve gelir eşitliksizliğin en yoğun yaşandığ1 ülkelerden biri olmuştur. 1988'de diktatörlüğün sona ermesinden sonra, daha önce diktatörlüklere karşı çıkanlar, halkın kendi kendini yönetmesi ve demokrasinin derinleşmesi talepleriyle İşçi Partisi'ni kurmuşlardır.

Porto Alegre kentinde, İşçi Partisi tarafindan uygulamaya konulan katılımcı demokrasi projesi sıradan vatandaşları hükümetin karar alma öncelikleriyle buluşturmuştur. Kamu kaynaklarının gecekondular gibi yetersiz alanlara ve temel sağlık hizmetleri gibi politika konularına tahsis etmesine yol açmıştır. Bu yönüyle sosyal adalete kuvvetli vurgu yapan bir uygulamadır. Katılımcı bütçeleme vatandaşların katılımcı olmayı, hükümetin işlevleri hakkında bilgi sahibi olmayı ve demokratik uygulamalara katılım sağladığı bir "demokrasi okulu" olarak tasarlanmıştır (Baiocchi, 2005).

1989 y1lında, 10 milyonu aşan nüfuslu Sao Paolo da dâhil olmak üzere, birçok belediye seçimlerini İşçi Partisi kazanmıştır. İşçi Partisi, kent bütçelerini yeniden düzenleyerek geniş katılımlı yaratıcı ve yenilikçi bir deney başlatmıştır. Rio Grande do Sul'nun1.3 milyon nüfusuyla en büyük sanayi şehri olan Porto Alegre, 7 milyar ABD dolarını aşan yerel bir ekonomisiyle uzun zamandır, insanları harekete geçiren aydınlar ve işçi sendikaları tarafından yönetilen ilerici bir sivil topluma ev sahipliği yapmakla ünlenmiştir (Dünya Bankası, 2003, s. 1).

1989'den sonra, İşçi Partisi, Porto Alegre'de ardı ardına üç kez belediye seçimleri kazanırken oy oranlarını da arttırmıştır. Uzun yıllar boyunca süregelen yoksulluk, yetersiz konut üretimi, yetersiz sağlı bakımı, yaygın suç, yetersiz okullar, yetersiz planlanmış altyapı ve hizmetlerine erişim sorunlarındaki gözle görülür iyileşmeler sonrası Brezilya'nın büyük kentleri tercihlerini İşçi Partisinden yana kullanmaya başlamışlardır. Porte Alegre kenti, göç, yoksulluk kayıt dış1lık ve mali sorunlar yaşarken mali reformlar sonrası dikkat çekici başarılar elde etmiştir.

1989'da yüksek okuryazarlık oranlarına rağmen, Porto Alegre diğer Brezilya şehirlerinin yaşadığı gelir eşitsizliğini benzer şekilde yaşıyordu. Nüfusun üçte biri, şehir çevresinden kötü hizmet verilen gecekondu mahallelerinde yaşıyordu. 1989 ile 1996 arasında katılımcı bütçe uygulamaları sonucunda temiz su hizmetlerine erişimi olan hanelerin oranı \%80'den \%98'e yükseldi. Belediyenin kanalizasyon hizmetini sunduğu nüfus $\% 46$ 'dan $\% 85$ 'e yükselirken; okul sayısı dört kat arttı. Devlet okullarına kayıtlı çocukların sayısı ikiye katlandı. 1986'da kamu konutlarından faydalanan kişi sayısı yalnızca 1.700 iken bu rakam 1989'da 27.000 kişiye yükseldi. Yoksul mahallelerde, her yil 30 kilometrelik yol asfaltlandı. Vergi ödeme motivasyonunu etkileyen önemli faktörlerden biri olan şeffaflığın sağlanması sonucunda gelirler yaklaşık \%50 oranında artış kaydedildi. Yatırım için bütçe kaynakları 1992'de 54 milyon ABD doları iken 1996'da 70 milyon ABD dolarına çıtı. Porto Alegre, katılımcı bütçe uygulaması esnasında eşine az rastlanan kararlarda alındı. Eski elektrik santrali alanı için beş yıldızlı otel inşa edilmesi projesi reddedilerek halka açı bir park yeri ve kongre salonu inşa edildi. Guíaba belediyesi, yeni istihdam vaatleri ve Ford Motor'un baskılarına rağmen, önerilen otomobil fabrikasını reddetti. Genel olarak kişi başına düşen gelir, işgücüne katılım ve istihdam konusunda 
yeterli ve anlamlı başarılar kazanılmamasına rağmen Porto Alegre'yi çevreleyen iyimserlik ve başarı duygusu dalga dalga dünyaya yayıldı. Bunun temeldeki nedeni ise insanlara katılımc1lık ve karar vermenin bir parçası olduklarını hissettirmesidir. Günümüzde 80'i aşkın Brezilya şehri, Porte Alegre'nin bu dönüşümünü takip ederek Porto Alegre modelini uygulamaktadır. (Goldsmith ve Vainer, 2001), (Sousa, 1998, s. 461-63)

Brezilya'daki katılımcı bütçe hareketinden ilk etkilenen Latin Amerika olmuştur. 1990'ların sonlarında ve 2000'lerin başında, Brezilya'nın komşuları, ikinci dalgada katılımeı bütçelemeyi kabul etmişlerdir. Hareketi takip eden 10 yıllık sürede Latin Amerika'da katılımcı bütçeyi uygulayan şehir sayısı 200'e erişmiştir. Örneğin Peru'da, ulusal anayasa tüm belediyelerde katılımcı bütçe kullanmasını gerektirecek şekilde değiştirilmiştir. Ayrıca, Arjantin, Ekvator, Uruguay ve Venezuela'daki şehirler ve belediyeler tarafindan katılımcı bütçe kabul edilmiştir (Wampler, McNulty, Touchton, 2017, s. 1).

Latin Amerika'da genel beklenti, sınırlı kaynakların etkin kullanımı, şeffaflık, sosyal hesap verebilirlik araçları ile yolsuzlukların azaltılmasıdır. Bununla birlikte, resmi olarak Porto Alegre uygulamasından ilham almış olmalarına rağmen bu hareketler sonucunda politik olarak motive olmuş ve güçlenmiştir. Bu ülkelerdeki diktatörlüklere karş1 yerel halk tepkilerinin geliştiği görülmüştür. Diğer yandan ise özellikle 2000 yılından sonra Dünya Bankasının 'da yoksullukla mücadele politikalarında katılımcı bütçe uygulamalarına destek vermesi konuya olan ilgiyi artırmıştır (Nelson Dias, 2014, s. 33-34).

Avrupa'da Katılımcı Bütçelemenin gelişimi ve yöntemleri Latin Amerika'dan oldukça farklı bir seyir izlemiştir. Genel olarak artan seçim yoksunluğu ve siyasi hoşnutsuzluk, batı dünyasındaki siyasal sistemlere, meşruiyetlerini bir kez daha göstermek için baskı yapmaya başlamıştır. Birçok ülkede yerel yönetimler, finansal sorunlarla mücadele etmek zorunda kalmıştır. Bu süreçte giderek artan sayıda belediye, katılımcı bütçelemeyi geliştirerek finansal zorlukları aşma ve hizmet üretme aracı olarak STK ve gönüllüleri sürece dâhil etmiştir Ancak referans noktaları esas olarak Porto Alegre olsa da, önerilen yöntemler farklılık göstermektedir (Sintomer, Herzberg,Röckevd, 2012).

Avrupa'da ilk katılımcı bütçe uygulamaları 1994'te İtalya'da (Grottammare), 1996'da İngiltere'de (Salford) ve 1998'de Almanya' da (Monchweiler) gerçekleştirilmiştir Katılımcı bütçe STK aktivistlerinin ve ayrıca 2001 Porto Alegre'deki sosyal forumlara katılan yerel hükümet temsilcileri ve politikacıların katkıları sonucu Avrupa'da hızla yayılmıştır. Dünya Sosyal Forumu'nun paralel bir etkinliği olan Yerel Yönetimler Forumu'na katılanlar, Avrupa'da katılımc1 bütçenin yayılmasında özellikle önemli bir rol oynamışlardır (Sakınç ve Bursalıoğlu, 2014, s. 5).

Katılımcı Bütçe konusunda özellikle 2010 yılı sonrası ilerlemeler sağlanmıştır. Farklı ülkelerde yaygınlaşmış ve uygulama alanı bulduğu kent sayısı artmıştır. En dinamik yayılma süreci Polonya'da yaşanmaktadır. Porto Alegre modelinin en yakın uyarlamaları ise çoğunlukla İspanya ve İtalya'da bulunmaktadır. İber Yarımadası'ndaki katılımcı bütçe süreçleri dikkat çekmektedir. Avrupa'da, özellikle Fransa, İtalya, Portekiz ve İskandinavya'da en yaygın yaklaşımlar, yöneticiler, politikacılar ve vatandaşlar arasındaki iletişimi geliştirmek ve güçlendirmek için yapılan mahalle toplantılarına dayanmaktadır. Muhafazakâr hükümetler de bu duruma uzak durmayarak Almanya örneğinde olduğu gibi bu süreçte aktif hale gelmişlerdir. Çoğu Batı ve Kuzey Avrupa ülkesinde, çeşitli yerel yönetim ağları ve devlet kuruluşları katılımcı bütçeyi tanıtmaya çalışmakta ve desteklemektedir. Katılımcı bütçeleme Doğu Avrupa'da ise, Dünya Bankası, UNO, USAID, GIZ gibi uluslararası kuruluşlar tarafından desteklenmekte ve yerel ortaklarla iş birliği yapılmaktadır (Nelson Dias, 2014, s. 33-34).

Giderek artan bir şekilde, bağışçılar ve uluslararası kuruluşlar, kâr amacı gütmeyen kuruluşların yaptığı gibi katılımcı bütçeyi desteklemektedir. Sahra Altı Afrika'da uluslararası STK'lar ve çok taraflı kalkınma bankaları, katılımcı bütçenin Kongo, Kenya, Mozambik, Güney Afrika ve Tanzanya'da uygulanmasına yardımcı olmuşlardır. Kuzey Amerika'da, kâr amacı gütmeyen Katılımcı Bütçeleme Projesi, hem New York, Chicago gibi büyük hem de Greensboro 
,Vallejo gibi daha küçük yerlerde katılımcı bütçe projeleri üstlenen şehirlere teknik yardım ve araçlar sağlamıştır. Avrupa'da ise, Paris ve Madrid şu anda bu alanda öncü nitelikte şehirlerdir ve bu kentler aynı zamanda dünya çapında söz konusu alanda çalışan kentlere teknik destek sağlamaktadır. Madrid, açık kaynak kodlu sivil katılım portali geliştirmiş ve bu sistem 50 şehir ve ek olarak Buenos Aires ve Paris'in ihtiyaçlarını karşılayacak şekilde bu kentlere adapte edilmiştir. Jalisco (Meksika), Buenos Aires (Arjantin), Tiflis (Gürcistan), Paris (Fransa) ve Madrid (İspanya) gibi şehirler katılımcı bütçeleme öğrenme sürecini ileri düzeylere götürmüş durumdadırlar (Wampler, McNulty, Touchton, 2017, s. 1).

\section{Katılımcı Bütçenin Yarattığı Değişimler}

Katılımcı bütçeleme son çeyrek yüzyılın en başarılı demokratik katılım örneklerini sunmuştur. Porto Alegre belediye bütçesinin ilk defa katılımcı anlayışla kullanıldığı 1989 yılından bu yana, hızla artan katılımcı bütçe uygulamaları bugün dünya çapında 1,630 dolayında kentte uygulanmaktadır. Bu süreçte ortaya çıkan kazanımların birçoğu birbirine yakın ve birbirini tamamlar niteliktedir. Bu kazanımları kendi içerisinde sınıflayarak dokuz başlık altında toplayabiliriz (https://www.participatorybudgeting.org/).

1. Uygulamada Esneklik: Katılımcı bütçeleme uygulamasının en önemli özelliklerinden bir tanesi, gelişmiş ya da gelişmekte olan ülke ayrımından bağımsız olarak her ülkenin geleneksel idari yapısına, demokrasi anlayışına uyarlanabilmesidir. Bu esneklik, her ülkede standart olmayan farklı katılımcı bütçe uygulamalarının gelişimine neden olmuştur.

2. Katılımcılık ve Aidiyeti Artırmak: Katılımcı bütçe uygulaması sürecinde vatandaşlar doğrudan karar verme sürecinde yer aldıkları için yıl boyunca birçok forum, toplantı, çalıştay gerçekleştirilmekte ve bu süreçte vatandaşlar kamu kaynaklarının ne şekilde kullanıldığını izleme, sosyal politikalar arasında tercihte bulunma ve kamusal kaynakları önceliklerine göre dağıtma firsatı bulabilmektedirler. Bu uygulama sayesinde, gelir düzeyi düşük ve politik açıdan dezavantajlı kesimlerin de karar alma süreçlerine katılma firsatı oluşmaktadır (Yalçın, 2015, s. 314-315). Oy kullanmak ve yönetenleri seçmek dışında karar süreçlerine katılım sağlamayan kişilerin siyasi sürece dâhil olmalarının insanlara bir aidiyet duygusu katacağını ve önemsenmenin sonunda sahiplenmenin geleceğini söyleyebilir.

3. Açıklık ve Şeffaflık Sağlamak: Şeffaf ve katılımcı bir bütçeleme süreci yolsuzlukların ve benzeri sorunların azalmasına katkı yapmaktadır. Katılımcı bütçenin sağlayacağ faydaların en başında bütçe kararlarının açık ve şeffaf olması gelmektedir. Bu, bütçenin de vazgeçilmez ilkelerinden birisidir. Bu anlamda katılımcı bütçe, bütçenin temel ilkesini güçlendirici niteliktedir. Kamusal kararların daha şeffaf hale getirilmesi, yönetimlerin yetkililerinden ötürü sorumluluklarını patronaj, kayırmacılık ve yolsuzluk risklerini azaltarak yapmalarına neden olmaktadır.

4. Bütçe Sürecini Değiş̧irmek: Katılımcı bütçe, kamu maliyesinde aşağıdan yukarıya bir yaklaşım olduğu için demokratik bir maliye politikası uygulamalarında önemli bir araç haline gelmiştir. Bugüne kadar bütçe yapma süreçlerinde genel eğilim, yukarıdan aşağ doğru bütçeleme yapılmasıdır. Katılımcı bütçe, vergi ödeyenlerin vergilerinin bir kısmının nereye kullanılacağına kendilerinin karar verdiği bir sistemdir. Bu yönüyle katılımcı bütçeleme, bütçe hakkının ruhuna uygun bir biçimde kullanılması için doğrudan bir uygulamadır.

5. Temsili Demokrasinin Aksaklıklarını Azaltmak: Bütçe genelde ilgili bürokrasinin ve seçilmiş yetkililerin tercihlerinin bir göstergesi olarak kabul edilmiştir. Seçim sistemlerine bağlı olarak salt çoğunluğun altında bir oranla da yönetme yetkisini bir siyasi parti alabilir. Yüzde 30-40 aralığında oy alarak seçilen bir iktidar veya belediye başkanının muhalif olduğu daha büyük bir kitle mevcuttur. Seçilen kesimin tercihlerinin 
yansıması tek başına tüm halkın beklentisini karşılamayabilir. Bu anlamda temsili demokrasinin ortaya koyduğu aksaklıkların bir kısmını giderici etkisi olmuştur. Kamu maliye politikasının amacı piyasa başarısızlıklarını telafi etmektir.

6. Uzlaşmacı ve İşbirliğine Dayalı Karma Model Olması: Katılımcı bütçe, doğrudan demokrasi ve katılımcı demokrasinin harmanlanmış halidir. Doğrudan demokrasi, kolektif karar alma mekanizmasında ölçeğin artması sonucu sıklıkla kullanılabilecek bir araç olmaktan çıkmıştır. Anayasal değişiklikler, önemli konularda referandumlar ile uygulansa da rutin binlerce kararın alınması aşamasında her seferinde doğrudan demokrasi araçlarını kullanmak zaman ve maliyet açısından olanaksız hale gelmektedir. Buna karşın temsili demokrasinin tüm dünyada bir güven krizi yaşıyor olması, temsilcilerin belirlenmesinde yaşanan sorunlar, temsilciler ve ekonomik güç arasındaki bağlantının giderek artması ve nedensellik göstermesi çok sayıda insanı karar sürecinde etkisiz hale getirmektedir. $\mathrm{Bu}$ nedenle daha küçük ölçekli yerleşim yerlerinde vatandaşların kendilerini ilgilendiren ortak konularda karar verirken katılımcı anlayışla hareket edilmesi doğrudan demokrasiyi güçlendirmektedir. Bu nedenle yönetenlerin yetkilerinin bir kısmını vatandaşla paylaştı̆̆ karma bir modele dönüşmektedir.

7. Optimal Kaynak Kullanımı ve Rasyonel Karar Almak: Kararların dar bir coğrafi alanda alınıyor olması ve o bölgenin insanların kendi toplumsal gereksinimlerini daha iyi bilmeleri sonucunda daha rasyonel kararlar alınması beklenmektedir. Bu rasyonel karar varsayımının gerçekleşmesi durumunda kaynakların daha etkin tahsis edileceği ve yeniden dağılım mekanizması üzerinde iyileştirici etki yapması beklenir. Bunlar kamu maliyesinin en temel fonksiyonlarının doğru çalışması anlamına gelmektedir. Katılımcı bütçeleme bu anlamda kaynakların optimum şekilde kullanılması ve bu süreçte ortak akılla rasyonel seçimler yapılması esasına dayanmaktadır.

8. STK ve Aktif Vatandaşı̆ığın Gelişmesi: Katılımcı bütçelemenin başarısı ve pek çok ülkede kentte uygulama alanı bulması, kentler genelinde daha fazla dernek ve kooperatif oluşumuna ilham kaynağı olmuştur. Sivil alanın genişlemesi, aktif vatandaşlık örneklerini çoğaltarak toplumun daha fazla demokratikleşmesini teşvik etmiştir. $\mathrm{Bu}$ oluşumlar, aktif siyasete, hak savunuculuğu ya da lobi faaliyetine dönük değildir. Bunun çarpıcı bir örneği, 1989'dan beri yaratılan konut kooperatiflerinin sayısıdır. 1990'da konut kooperatifi yokken, 2000'de 100'e yaklaşmıştır (Baiocchi, 2003, s. 58). Programın erken başarısı, sivil toplumda ve mahallelerde daha fazla siyasi faaliyete neden olarak kentte bir dayanışma duygusunun gelişmesine yardımcı olmuştur. Çünkü insanlar programın, katılımcılar açısından sadece bir danışma organı olmayıp gerçek bir güç sunduğunu görmüştür. $\mathrm{Bu}$ durum politik süreçlere yabancılaşmış olan kesimleri yeniden örgütlenmeye ve katılıma motive etmiştir. Böylelikle, kişiler arasındaki farklılıkları en aza indirgemek için çaba sarf edildiği gibi, mahalleler arasındaki farklılıklar da azalmıştır.

Yeniden Dağılım Mekanizması: Katılımcı bütçeleme süreci, demokratik proje olarak gelişmekle kalmadı bazı iktidar gücünü ve idari yetkileri devlet dışı sivil toplum kuruluşlarına aktararak bütçe fonksiyonunu başarılı bir şekilde yeniden gerçekleştirdi. Eşitsizlikleri azaltırken kaynak dağılım mekanizmasını yeniden sosyal kesimler lehine düzenledi.

\section{Katılımcı Bütçe Modelleri}

1989 yılında Porto Alegre kentinde başlayan katılımcı bütçe hareketi artık küresel ölçekte uygulanan, tartışılan uygulanan bir bütçe yöntemine dönüştü. Bu kadar büyük ölçekte uygulama alanı bulunan bir sistemin tek tip olarak uygulanması beklenemezdi. Ülkeler arasındaki ekonomik, sosyal, siyasal farklılıklar sonucunda her ülke kendi gerek ve gerçeklerinden hareketle farklı modeller oluşturdular. Başlangıçta küçük kentlere uygun olduğu düşünülen katılımcı bütçe modeli, giderek büyük kentlerde de uygulama alanı buldu. Bu çalışmada uygulamanın doğduğu "Porto Alegre kenti modelini başlangıç noktası olarak kabul ederek ele alındı. Diğer seçimlerde 
ise Paris ve Seul örneğini incelenecektir. Güney Kore'nin başkenti Seul bu alanda uygulamanın yapıldığg en büyük nüfusa sahip kent konumundadır. Fransa'nın başkenti Paris ise bu alanda en fazla kaynak ayıran kentlerin başında gelmektedir.Bir yandan Porte Alegre, Güney Amerika modelinin temelini oluştururken incelenen diğer iki kent Avrupa ve Uzakdoğu'dan seçilmiştir. Çalışmamızda 3 farklı kıtadan kent uygulamaları ele alınmıştır.

\subsection{Porto Alegre Katılımcı Bütçe Modeli}

Bilinen ilk katılımcı bütçeleme projesi olması nedeniyle Porto Alegre uygulaması, pek çok çalışmada öncelikli olarak ele alınmıştır. Çalışmamızın katılımcı bütçelemenin tarihçesinin incelendiği bölümde de Porte Alegre uygulaması incelenmiştir. Bu bölümde Porto Alegre uygulamasında sürecin nasıl ilerlediğini ele alınmaktadır. Şekil 1 yıllık bütçeleme döngüsünü göstermektedir.

Şekil 1. Porto Alegre y1llık katılımcı bütçeleme döngüsü

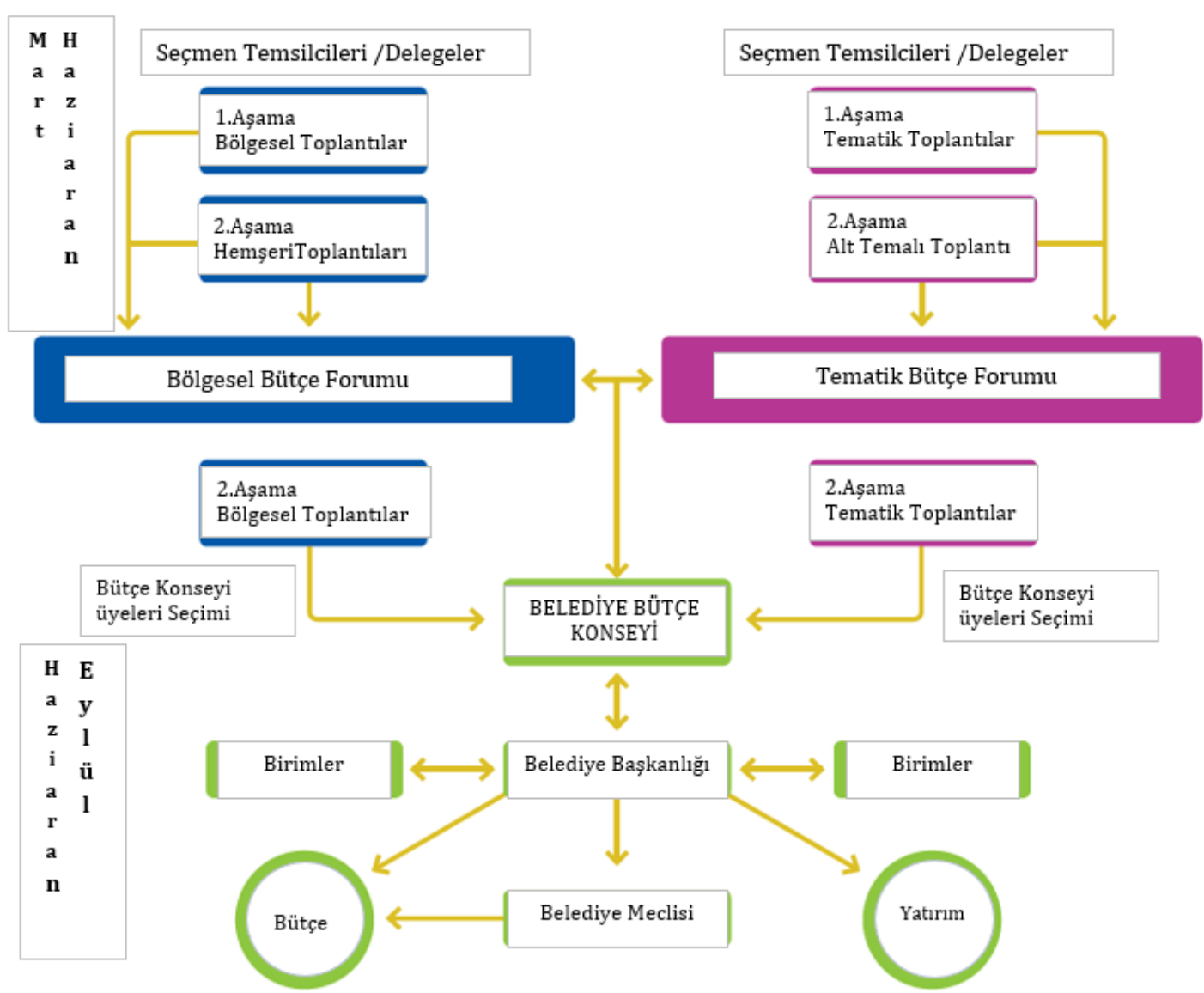

Kaynak: Wampler (2000); Wampler (2007, ss. 21 -54) çalışmalarına dayanılarak uyarlanmıştır.

Porte Alegre katılımcı bütçe süreçleri, geleneksel oy verme ve halk katılımı kriterlerinden farklı olarak düşük gelirli kent sakinlerine, vatandaş olmayanlara ve gençlere yer vererek kamusal karar sürecinde dışlanan kişi ve grupları da içerecek ya da öncelik verecek şekilde tasarlanmıştır (Bahçeci, 2009).

Katılımcı bütçe süreci Mart'tan Haziran'a kadar her bölgede bir dizi toplantı ile başlamaktadır. Belediye coğrafi olarak başlangıçta 16 bölgeye ayrılmıştır. 2007 sonrası bölge sayısı bir artırılarak 17 olmuştur. Vatandaş katılımına açı 17 meclis şehrin farklı coğrafi bölgelerini temsil etmektedir. Bu meclislerde mahalle ve altyapı yatırımları ve bölgesel öncelikler için oy kullanmak, bütçe formuna ve Katılımcı Bütçe Konseyi'ne katılacak temsilcileri seçmek, projelerde izleme görevi yapılmaktadır. Bütçe formlarına katılacak kişi sayısı kullanılan oy sayısı 
ile orantılıdır. Katılımı teşvik etmek için mahalle meclisinde katılım ne kadar yüksekse bütçe formuna mahallelerden daha fazla temsilci göndermektedir. Bu sadece forum için geçerlidir. Forum toplantılarına katılım tüm vatandaşlara açık olmakla birlikte yalnızca delegelerin oy hakkı vardır. Delegelerin görevleri ise halk meclislerinden gelen talepler doğrultusunda listelere öncelik vermek ve devam eden müzakereleri sürdürmek ve çeşitli şehir kurumları tarafindan projelerin uygulanmasını izlemektir. Katılımcı Bütçe meclisinde ise her mahalleden eşit sayıda temsilci bulunur. Bölünmüş olan bölgelerin temsilcileri gönüllü görev yapar ve katılımcı bütçe komitesinde yerel yönetim yetkilileriyle beraber çalışırlar (Smith ve Fletcher, 2017).

Birinci ve ikinci turlar olarak adlandırılan bölgesel toplantılarda katılımcı bütçeleme meclisleri ve bölgesel meclisler ayrı ayrı toplantılar düzenlemektedirler. Bu toplantılar Belediye Meclisi tarafından koordine edilse de gündemleri yerel liderler, vatandaşlar, STK ile ortak belirlenmektedir. Ayrıca, STK'lar "aracı" rolünü üstlenerek, çeşitli yerel toplantılar düzenleyerek, vatandaşla bir araya gelerek talep ve isteklere aracılık etmektedirler. Doğrudan demokrasiye dayalı bu bölgesel toplantıların iki amacı vardır. İlk amaç, yerel sorunları tartışmak ve daha sonra yerel yatırım önceliklerini demokratik olarak kararlaştırmaktır. Bu tartışmalara herhangi bir vatandaşın, STK'nın veya belediyelerin katılımı mümkündür.

Diğer yandan ikinci amaç olarak tematik toplantılar düzenlenmektedir. Yerel sorunların belirlenmesi ve bu sorunlara karşı çözüm projelerin ortaya konulması amacıyla yapılan bu toplantılarda o yıl içerisindeki ele alınacak ana temalar ve öncelikler belirlenmektedir (Sakınç ve Bursalığlu, 2014, s. 5). Porto Alegre 'deki katılımcı bütçeleme modelinde bölgesel bütçe ve tematik bütçe toplantıları eş anlı olarak devam etmektedir. Çevre, eğitim, sağlık ve sosyal hizmetler ve ulaşım gibi kentin ortak sorunları ile ilgili konular tematik meclislerde ele alınmaktadır.

Katılımcı Bütçe Konseyi Bütçe sürecinde ana katılımcı kurumdur. Seçilen vatandaşlar belediyenin maliyesi ve bütçesi ile burada tanışmaktadırlar. Bütçe Konseyi, kaynak tahsisi için genel kriterleri tartışarak belirlerler ve bölge ve temaların önceliklerini burada savunurlar. $\mathrm{Bu}$ oturumlarda vatandaşlar ve sivil toplum temsilcileri ile belediye görevlileri arasında bütçe kararları konusunda müzakereler yapılmaktadır. Katılımcı Bütçe Konseyi görevlerini iki aşamada gerçekleştirilmektedir. Öncelikle Bütçe Konseyi, bütçe teklifi hazırlanıp yürütücü tarafından 30 Eylül'de yasama organına gönderilinceye kadar, gelir ve gider kalemlerini ve kaynak tahsisine ilişkin genel kriterleri tartışmakta ve Eylül ayından Aralık ayına kadar, yatırım planını hazırlanmaktadır. Öncelik verilen çalışmaların ve faaliyetlerin ayrıntılı bir listesi ve böylece her bölge ve tematik alan için programlanan kaynakların dağılımı belirlenmiş olmaktadır (Sousa, 1988, s. 322). Bölgesel bütçe forumları tarafindan önceliklendirilen ve idare tarafindan kabul edilen yatırımlara bir dizi kaynak dağıtım kuralı uygulanmaktadır. Bu kurallar gözden geçirilerek izleyen yıl içinde dağıtım esaslarına karar verilmektedir. Bu görevlerde Konsey, idare yetkililer ile yakın çalışır. Seçilenlerin bu süreçte gücü kötüye kullanmalarını engellemek için meclis üyeleri sadece iki ardışı görev dönemi için seçilebilmektedirler. Bütçe forumlarında halk sadece gözlemci statüsüne sahip olmasına rağmen, Bütçe Konseyi toplantıları halka açıktır (Gret ve Sintomer 2005, s. 44).

Merkezi planlama ofisi GAPLAN (Gabinete de Planejamento), yönetimin farkl1 bölümleri arasında bütçenin teknik yönlerini koordine etmekle görevlidir. Bu ofis, katılımcı bütçe konseyinin çalışmalarını müzakere etmekte ve desteklemektedir. Halkla İlişkiler Departmanı çalışanları katılımcı süreci artırmak amacıyla çalışırlar, derneklerin gelişimini desteklemekte ve bölgesel bütçe forumlarını kolaylaştırmaktadır. Her bütçe bölgesine bir koordinatör atanmaktadır. Online ortamdaki "proje yönetim sistemi" ile projelerin aşamaları vatandaşlar tarafından takip edilebilmekte ve vatandaşlar idarenin faaliyetleri hakkında araştırma yapmalarına yardımcı olunmaktadır. 


\subsection{Fransa: Paris Katılımcı Bütçeleme Modeli}

1789' da Fransız ihtilalinde İnsan ve Yurttaş Hakları Bildirisi'ni kabul etmiş Fransa, aradan geçen zamanda da pek çok sosyal eylemin merkezi olmuştur. Paris'te uzun yıllardır devam eden ifade özgürlüğü geleneği bulunmaktadır. Paris, tarih boyunca pek çok üçüncü dünya aydınının sığınma yeri olmuştur. Tüm bunlara karşın vatandaşın katılım sorunu, Paris siyasetinde ve entelektüel ve akademik çevrelerde sürekli tartış1lmıştır (Gürcan, 2011, s. 183).

Fransa'nın siyasal kültürü yüzyıllar boyunca yukarıdan aşağıya ve merkezileştirilmiş bir yaklaşımla örgütlendi. Katılım biçimleri bir ülkenin sosyo-politik geleneğinden etkilenip şekillendiğinden, Fransız vatandaşlarının katılımı, az sayıdaki fırsatlarla birlikte arzu edilen düzeyde olmadı. Bununla birlikte, katılımcı bir yönetişim biçimlerini destekleme konusunda kamuoyunda ciddi baskılar oluştu. Fransa, 90'lı yılların başından beri, demokrasiyi güçlendirmek için yerel düzeyde vatandaş katılımını arttırmaya çalıştı. 2002 yılında yasal düzenlemeler gerçekleştirdi. Bu düzenlemeler sonucunda mikro düzeydeki danışma organları olan "Conseil de Quartiers" (mahalle konseyleri) oluşturuldu. Belediye başkanı, mahallelerin coğrafi sınırlarını ve konseylerin çalışma kurallarını belirlemekte serbest kılındı. Paris'te 123 mahalle konseyi oluşturuldu (Medenian ve Scully, 2018).

2001 yılında kendilerini haklarından mahrum edilmiş hisseden yerel vatandaş grupları arasında toplumsal huzursuzluğun doruğa çıktığı dönemde Paris belediyesi sol iktidarın eline geçmişti. Zorda olan belediye bir değişim zamanı geldiğinin farkına vardı. Tarihsel olarak, vatandaş katılım sorunu, Paris'in siyasetinde merkezi bir sorun olarak durmaktaydi. Şehrin sakinleri karar verme sürecinin dışında bırakılmaktan ötürü her platformda hoşnutsuzluklarını dile getirmekteydiler. Bu dönemde, vatandaşların karar alma sürecine katılımına yönelik daha geniş, ülke çapında bir hareket vardı ve bu hareketin sonucunda vatandaşları altyapı ve çevre ile ilgili kararlara dahil etmek için çeşitli yasalar çıkarılmıştı. "Vatandaşları bilgilendirmek ve bakış açılarının karar vermede dikkate alınmasını sağlamak misyonuna sahip bağımsız, idari bir makam olan Vatandaş Komitesi” kamuoyuna tanıtılmıştı. Bunlar Paris için işbirlikçi bir kentin evriminde yeni bir adım oldu. Sadece bilgi vermenin artık yeterli olmadığı anlaşılmıştı. Belediye Başkanı Hidalgo'nun seçilmesinden sonra Eylül 2014'te 20 milyon Euro'luk finansman yaratılarak 15 proje önerildi ve projeler için vatandaşlar davet edildi. Çevrimiçi oylama ve geleneksel oylama yapıldı. 15 projeden 9'unun kabul edildiği oylamaya katılan 41.000'den fazla kişinin yüzde 60'1 İnternet üzerinden oylarını kullandılar. 2014-2020 yılları arasında ise katılımcı bütçe ile harcanacak projeler için 500 milyon Euro tahsis edilmesi fikri benimsendi. 2015 yılında çevrimiçi oylama yönteminin başlatılmasının ardından Paris sakinleri 5.000'den fazla fikir önerdi ve bunlara 67.000'den fazla kişi oy verdi (Veron, 2017).

2016 y1lına gelindiğinde 158.964 kişi katılımcı bütçelemeye katıldı ve bu katılımcılar, okullar için ayrılan 10 milyon Euro da dahil olmak üzere yaklaşı 100 milyon Euro'nun nereye harcanacağı konusunda oy kullandılar. Şehirdeki işçi sınıfı mahalleleri için 30 milyon $€$ kaynak ayrıldı. Şehir genelinde 37 proje, 587 ilçe projesi ve 20 okul projesi vardı. Bunlardan 219 proje uygulamaya hak kazand1. Özellikle 2016 yılı uygulamas1 Paris'te sisteme ve uygulamaya olan şüpheleri ortadan kaldırdı. Başlangıçta pek çok kişinin şüpheyle yaklaştığı uygulama siyasi iradenin arkasında durması, yeterli kaynak ayrılması, ilçe belediyelerinin katılımcı bütçe için sağladıkları her 1 avro için Paris Belediyesinin 2 avro koymayı taahhüt etmesi ve gerçekleştirmesi karşısında Parisliler de binlerce fikir sunarak sistemin yerleşmesine katkı yaptılar (Carlson, Jake, 2017; Napolitano, 2015).

Paris şehir meclisi yenilikçi katılımcı mekanizmaların geliştirilmesini destekleme konusunda adımlar atmıştır. $\mathrm{Bu}$ süreçte müzakere, eğitim ve katılımcılık mekanizmaları güçlendirilmiştir. 2017 itibariyle, Paris'te yedi danışma kurumu bulunmaktadır. "Conseil desquartiers" (Mahalle Konseyi) daha önceki dönemlerde de bulunmaktaydı. Conseil Parisien de la Jeunesse" (Gençlik Konseyi) ve "Etudiant de Paris-le Conseil" (Parisli Öğrenci Konseyi), "Conseil desGénérations (Gelecek Nesil Konseyi) sendikaların, kamu görevlilerinin, derneklerin 
ve rastgele seçilmiş sakinlerin seslerini duyurabilecekleri ekonomik, sosyal ve çevresel konular hakkında tartışma alanı açtı. Conseil desCitoyens" (Vatandaş Konseyi) şehir tarafindan belirlenen düşük gelirli mahallelerde yaşayan sakinler için oluşturulurken, "Conférence de citoyens" (Vatandaş konferansları) vatandaş meclislerine benzer işlevler yüklendi. "Conseil de la Nuit" (Gece Konseyi) ise Paris'teki gece boyunca güvenlik, ulaşım, kültür ve ticaret konularına odaklandi. (Medenian ve Scully, 2018).

Danışma organlarına ek olarak kent sakinleri proje yönetimi, dijital araçlar, halkın konuşması ve kentin nasıl çalıştığı hakkında bilgi edinmek için sivil atölyelere katılabilmekteydiler. New York ve San Francisco'dan sonra Paris kentinde de 7 yaşın üzerindeki sakinlere vatandaşların katılımını teşvik etmek için ücretsiz bir "Vatandaşlık Kartı" verilmiştir. Bu kart özel halk etkinliklerine, müzelere, belediye hizmetlerinin rehberli ziyaretlerine, eğitim atölyelerine ve daha pek çok etkinliğe erişim sağlamaktadır. Kart sahipleri, vatandaşlık sorunlarını tartışmak için ayda bir kez Paris Belediyesi'nde uzmanlar ve akademisyenler ile görüşebilmektedirler. Son yıllarda Paris, "sivil teknoloji” olarak da adlandırılan vatandaş katılımı için dijital araçlar denemede ve geliştirmede lider olarak kendini göstermiştir. Jemengage Paris uygulaması insanları, bulundukları yere, ilgi alanlarına ve uygunluklarına göre kısa süreli gönüllü görevler için STK'larıyla buluşturan bir uygulamadır. "Dans MaRue" vatandaşların çukurlar, bozuk oyun alanları, kayıp yol işaretleri vb. sorunlar hakkında şehri uyarmalarını sağlayan bir vatandaş raporlama uygulamasıdır. Kullanıcılar fotoğraf gönderebilir ve taleplerinin hangi aşamada olduğu hakkında bildirim alabilirler. "Sayın Belediye Başkanı bir fikrim var", Paris'lilerin belediye başkanlığı tarafindan incelenmek üzere farklı konularda fikirlerini sunabilecekleri dijital bir iş birliği alanıdır. Katılımcı bütçe uygulaması, vatandaşların belediye yatırım fonunun tahsisinde fikirlerini ve kararları paylaşması için çevrimiçi ve çevrimdışı bir platformdur (Medenian ve Scully, 2018).

Resmi katılımcı bütçe sitesi "https://budgetparticipatif.paris.fr" adresinden tüm işlemler ve süreçler takip edilebilmektedir. Çalışmamızda katılımcı bütçe sürecinin nasıl işlediği konusunda bu verilerden faydalanılmıştır.

Şekil 2. Paris katılımcı bütçe süreci

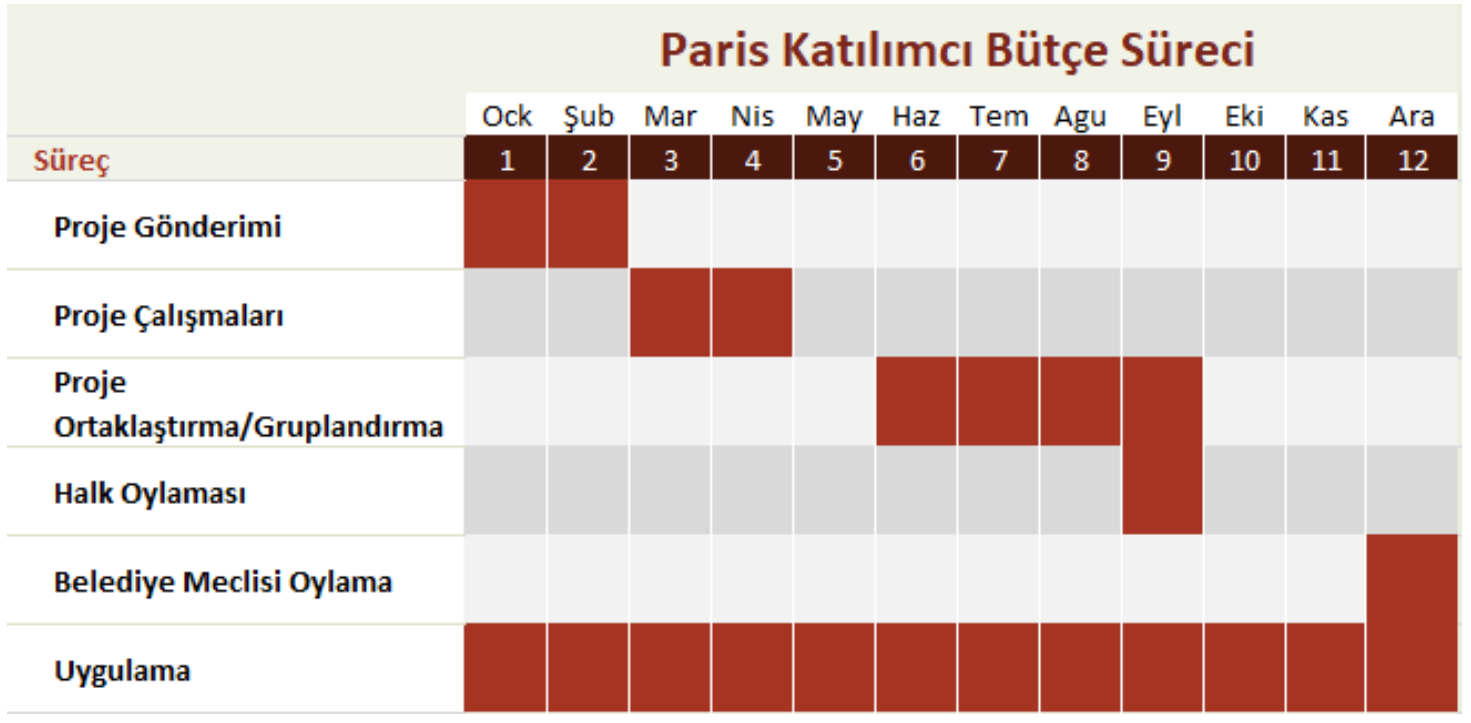

Kaynak: Budgetparticipatif.paris.

Paris katılımcı bütçe süreci beş aşamadan oluşmaktadır.

1.Aşama- Proje Gönderimi: Paris'te yaşayan herhangi kent sakini, dernek, vakıf, kulüp, gruplar, yaş ve milliyet kısıtı olmadan katılımcı bütçe sürecine katılabilirler. Katılımcılar, katılımcı bütçe web sitesi üzerinden Ocak ayında çevrimiçi olarak önerilerini sunabilmektedirler. Katılımcıların 
önerileri, analiz edilerek oylamaya sunulur. Kent sakinleri iki tür proje sunabilmektedir. Bunlardan birincisi kendi yaşadıkları semti, ilçeyi ilgilendiren projelerdir. İkincisi ise tüm Paris'i ilgilendiren projelerdir. Bu projelerle ilgili olarak belediye tarafindan halka açık toplantılar, çalıştaylar yapılmaktadır. Mahalle konseyi, dernekler, yerel kolektiflerle beraber iş birliği yapılır ve teknik destek sağlanır. Projenin kabul edilebilir olması için dört temel kriterin yerine getirilmesi gerekmektedir.
i. Kamu çıkarı olması
ii. Paris şehrini ilgilendiren konularla ilgili olması,
iii. Kamusal nitelikte bir harcama olması ve aşırı harcama gerektirmemesi
iv. Paris’te yaşayan kişi veya gruplarca sunulması.

2.Aşama- Proje Çalışmaları: İkinci aşamada, başvurusu yapılan projelerin değerlendirilmesine geçilmektedir. Projeler, ilk olarak, dört ana kritere cevap verip vermediklerine göre değerlendirilmektedir. İkinci olarak da teknik olarak uygulanabilir olmadığ 1 incelenmektedir. Kabul edilebilirlik çalışması tamamlandıktan sonra, kabul edilebilir nitelikteki projeler belediye uzmanlarına teknik inceleme için verilirler. Bu aşamada çok sayıda proje olduğu göz önüne alındığında, bu ön çalışmanın amacı projenin tamamlanmasındaki olası engelleri belirlemek ve maliyet tahmini yapmaktır. Kesin uygulama usulleri, eğer proje oylamada başarılı olursa daha sonra belirlenmektedir.

3.Aşama- Projeleri ortaklaştırma ve Gruplandırma: Ortak inşaat, tek bir proje içerinde benzer ya da birbirine yakın projeleri birleştirme sürecidir. Genelde farklı ilçelerde benzer talepler geldiğinde her ne kadar ilçe projesi gibi sunulmuş olsa da bu taleplerin her bölgeden yoğunlaşması, bu projeyi Paris'in tümünü ilgilendiren bir projeye dönüştürebilmektedir. Benzer projeler bir havuzda toplanıp birleştirilerek daha düşük maliyetlerle yapılabilmektedir. Birleştirilmiş projeler tek bir başlık altında toplanmaktadır. Oylamayı kazanması durumunda ana projeyi oluşturan alt projelerin her biri gerçekleştirilecektir.

Seçime sunulan projelerin son aşamasında, teknik olarak uygulanabilir projeler, her ilçedeki belirli komisyon toplantılarında ve Paris ölçeğinde incelenmektedir. Komisyonların sonunda, oylamaya sunulan projelerin nihai listesine, ilçe projeleri için ilçe Belediye Başkanı ve Paris projeleri için Paris Belediye Başkanı tarafindan karar verilir.

İlçe Projelerine karar verecek komisyonlar ise; (www.budgetparticipatif.paris)

- İlçe Belediye Başkanı veya Temsilcisi

- İktidar Temsilcileri (3 Kişi)

- Muhalefet Temsilcileri (2 Kişi)

- Paris Belediye Başkanı Temsilcisi

- Bölgedeki her yerel demokrasi organının bir temsilcisi: (Vatandaş Konseyi, Çocuk konseyi, Engelli Konseyi, Yabancilar Konseyi vb)

- Belediye Meclisi Temsilcileri (ilçe başına 3 ila 11 kişi)

- Mahalle Konseyi Koordinatörleri

- Yerel Kalkınma Ajansı Temsilcisi

- Hizmetler Genel Müdürü veya yardımcısı

- Dernekler temsilcisi

- Mahalle konseylerinin koordinatörleri (ilçelere bağlı olarak bir veya iki kişi)

- İlgili belediye birimlerinden temsilcilerinden oluşmaktadır.

Paris projelerine karar verecek Komisyon ise; (www.budgetparticipatif.paris)

- Yerel demokrasi, vatandaşların katılımı, ortak yaşam, gençlik ve istihdamdan sorumlu Paris Belediye Başkan Yardımcısı

- Kültürel miras, el sanatları, kültür işletmeleri, il meclisleri ile ilişkilerden sorumlu başkan yardımcısı 
- Finanstan, yarı halka açık şirketlerden, kamu sözleşmelerinden ve imtiyazlardan sorumlu Paris belediye başkan yardımcısı,

- Paris Konseyi'ndeki her siyasi grubun bir temsilcisi.

- Katılımcı bütçe web sitesinde kayıtlı Parisliler arasından kura ile seçilen (8 kişi)

- Bir veya daha fazla bireysel proje sunan (2 Kişi)

- Bir dernek adına bir veya daha fazla proje sunan (2 Kişi)

- Bir ilçe meclisi adına bir proje veya proje sunan (2 Kişi), ilçe özel kurullarının bir parçası olarak seçilen projeler arasında Platformda kayıtlı (2 kişi)

- Paris Gençlik Konseyi'nin bir temsilcisi

- Paris Öğrenci Konseyi Temsilcisi

4.Aşama: Oylama: Projenin yaşama geçirilebilmesi için oylanması gerekmektedir. Oy vermek için iki seçenek sunulmuştur. Bunlardan birincisi, katılımcı bütçe web sitesinden oy kullanılabilir veya Paris'in her yerine dağıtılan anketlerden biriyle web sitesinde yerleri belirtilmiş olan yerlerde, oy pusula ile oy kullanılabilmektedir. Proje sahipleri yeterli oy alabilmek için kampanyalar ile halka tanıtım yapmakta ve destek aramaktadırlar. Paris'te yaşayan tüm insanlar yaşına ve etnik kökenine bakılmaksızın Parisli olarak kabul edilmektedir. Bütün Parisliler oy kullanma hakkına sahiptir. Kişiler, ikamet yerine, işe ya da kişisel yakınlıklara bağlı olarak oy kullanacakları yeri seçmekte özgürdür ancak sadece bir bölgeye oy vermek mümkündür. Seçmenler, Paris projeleri ve ilçe projeleri için ayrı ayrı oy kullanmaktadırlar.

5.Aşama: Uygulama: Eylül ayında Parisliler tarafından oylanan projeler, Aralık ayında Paris Konseyi tarafından oylanarak Paris belediyesi çalışma programına dâhil edilmektedir. Ocak ayından itibaren ise kazanan projelerin uygulanmasına başlanmaktadır. "www.budgetparticipatif.paris" web sitesinde dijital haritalar üzerinde kazanan projelerin ilerleme durumu gösterilirken sitede aynı zamanda projelerle ilgili düzenli bilgilendirme yapılmaktadır. Ayrıca Facebook grubundan bilgiler aktarılmaktadır.

\subsection{Güney Kore: Seul Katılımcı Bütçeleme Modeli}

Güney Kore'de, katılımc1 bütçe için yerel düzenleme yapma önerisi 2002'de bir siyasi parti tarafindan yapılan önergeyle gündemde yer bulmuştur. 2004'te, Güney Kore'nin güneyindeki büyük şehirlerden biri olan Gwangu'daki Buk-gu kentinde, katılımcı bütçe için yerel yönetmelik hazırlandı. Bu yönetmelik Ulsan ve Dajeon gibi diğer şehirlere yayıldı. Ancak beklenen kadar ilgi görmedi. Güney Kore'deki "Katılımcı hükümet" olarak da bilinen Roh Muhyun hükümeti, yerel yönetimlere katılımcı bütçe sistemini tanıtmalarını ve uygulamalarını önerdi. Ağustos 2005'te Kore hükümeti, yerel yönetimlerde vatandaşların bütçe karar alma sürecine katılmalarına izin vermesinin önünü açan "Yerel Finans Yasasını" yeniden düzenledi. Yasa da sistem için bütçe büyüklüğü gibi somut kararlar vardı. Vatandaşların görüşlerini alma ve sistemin yerel yönetimlerde nasıl uygulanacağı konusunda süreçler belirlendi. Bununla birlikte, yerel yönetimler, başlangıçta sistemin ek bir idari yük olduğu düşüncesiyle mesafeli bir yaklaşım sergilediler. Bu anlamda 2010 yılında yapılan yerel seçimlerle beraber çarpıcı bir değişim yaşand. İktidardaki Demokrat Parti, seçim vaatlerinden biri olarak "katılımcı bütçeleme sistemini" ortaya koydu. Demokrat Parti'nin birçok adayı Seul'deki İlçe ve Belediye Meclisi başkanlığına seçildi. Doğal olarak, bu sonuç halkın katılımcı bütçeleme sistemine olan ilgisini arttırdı. Seul Belediye Meclisi, Mayıs 2012'de katılımcı bütçeleme sisteminin kurulmasıyla ilgili kararname çıkardı. Kararname katılımcı bir anlayışla hazırlandı ve belediye bürokratları, belediye meclis üyeleri, sivil toplum kuruluşları, uzmanlar ve halk temsilcileri arasında beş aylık çok paydaşlı bir müzakerenin sonucunda kararname kabul edildi. Sivil toplum hareketinde geniş deneyime sahip olan Wonsoon Bak, 2014 yılında Seul belediye başkanı oldu ve katılımcı bütçe sistemi onun döneminde önemli ilerlemeler kaydetti. Seul, dünyadaki katılımcı bütçeleme sistemini, nüfusu 10 milyonun üzerinde olan şehirlerden ilk uygulayan şehir oldu. Seul şehri bu süreçte katılımcı bütçeleme sisteminin değerlerini ve ilkelerini yansıtan en iyi örneklerden biri olmayı başardı (Lee,2016). 
Seul'un nüfusunun 10 milyonu aşması daha küçük ölçekli yerlerde katılımcı bütçe uygulamalarında sağlanan başarılarının büyük ölçekte nasıl işleyeceği konusunda önemli bir deneyim olarak araştırmacıların dikkatini çekmektedir.

Seul'deki bütçe oluşturma süreci, şehirlerin kaynaklarının bir kısmı için rekabet eden ya da bütçenin nasıl harcandığı üzerinde etkili olan çeşitli paydaşların ve baskı gruplarının aktif roller aldığı son derece politik bir konudur. Bu süreç, diğer uluslararası başkentlerden daha homojen olmasına rağmen, ülke içinde çok çeşitli olan şehir nüfusunun doğal özellikleriyle daha da karmaşıklaşmıştır. Çünkü uzun yıllar boyunca seçilen yerel yönetimlere yönelik olarak, seçilmelerine yardımcı olan kişi ve grupları korumak ve kollamak amacıyla bütçe oluşumunda bu gruplar lehine düzenlemeler yaptıkları yönünde suçlamalar hiç eksik olmamıştır. Seçilmiş siyasetçilerin kamusal fonların paylaşımında adil ve tarafsız davranmadıkları, siyasal himayeler yaptıkları görülmüştür (Lee, 2002). Diğer eleştiri konusu ise yerel meclislerin harcama kararlarında savurgan olmalarıdır. Bütçe kaynaklarını vatandaşlar arasında eşit ve adil kullanılmalıdır. Ancak yerel yöneticilerin kişisel hedeflerine daha fazla kaynak ayırdıkları öne sürülmektedir (Tobin, Hyunkuk, Wonhyukvd, 2014, s. 102-103).

Katılımcı bütçe uygulamasının Seul kentinde uygulanmasının asıl amacı, vatandaşları bütçe kaynaklarının dağılımı ve gözetimi sürecine doğrudan katılımını teşvik etmek gibi görünmektedir. Kamuoyunda ana beklenti yerel yönetimlerin başkanları ve meclis üyeleri tarafından sıklıkla başvurulan popülist politikaları ve bürokratik süreçleri azaltılması ve kamu kaynaklarının israfına veya verimsiz kullanılmasına yol açan nedenleri ortadan kaldırılmasıdır. (Lee, J, 2016).

Seul Modelinde önem arz eden 3 ana komite görev yapmaktadır. Bunlar;

a. Katılımcı Bütçe Komitesi: İşlevi, katılımcı bütçe için karar verme kuruluşudur. Başlangıçta en fazla 250 kişiden oluşan komite, daha sonra 300 kişilik bir kota ile sınırlandırılmıştır. 300 üyenin 25'ini Belediye Başkanı önerir. Diğer üyeler ise Belediye Meclisi Üyeleri ve Bütçe Okuluna katılan vatandaşlar tarafindan önerilir. Ayrıca başvuruda bulunan vatandaşlar arasından çekilişle üye kabul edilir.

Bu noktada Bütçe Okulu konusuna değinmek gerekmektedir. Bütçe okulu tüm vatandaşlara açıktır. Seul'da bütçe okulunda verilen eğitimi tamamlayan kişiler bütçe komitesine girmek için başvurabilmektedir. Bütçe Okulu'nun eğitim süresi 6 saat olup birinci gün, vaka çalışmaları aracılığ ile katılımcılara bütçe ve uygulama süreci ve katılımcı bütçe projelerinin önemi anlatılmaktadır. Bütçe okulunda şehir bütçesine katılım mekanizmalarının nasıl işlediği öğretilmektedir. İkinci gün ise Seul Kent bütçesi ve büyük projeler ile finansal bilgiler ve projenin nasıl kullanılacağı, katılım yöntemleri hakkında bilgi verilmektedir. Gün sonlarında ise grup çalışmaları ve örnek proje geliştirme çalışması yapılmaktadır. Eğitimler, vatandaşların kolay katılabilmesi için hafta içi, hafta sonu ve akşam saatlerinde de yapılmaktadır. Yıllık katılımcı sayıs1, 2014 yılında 773, 2015 yılında 1020, 2016 yılında 1152, 2017'de ise 2390 kişi olmuştur.

Şekil 3. Seul katılımcı bütçe komitesi cinsiyet dağılımı

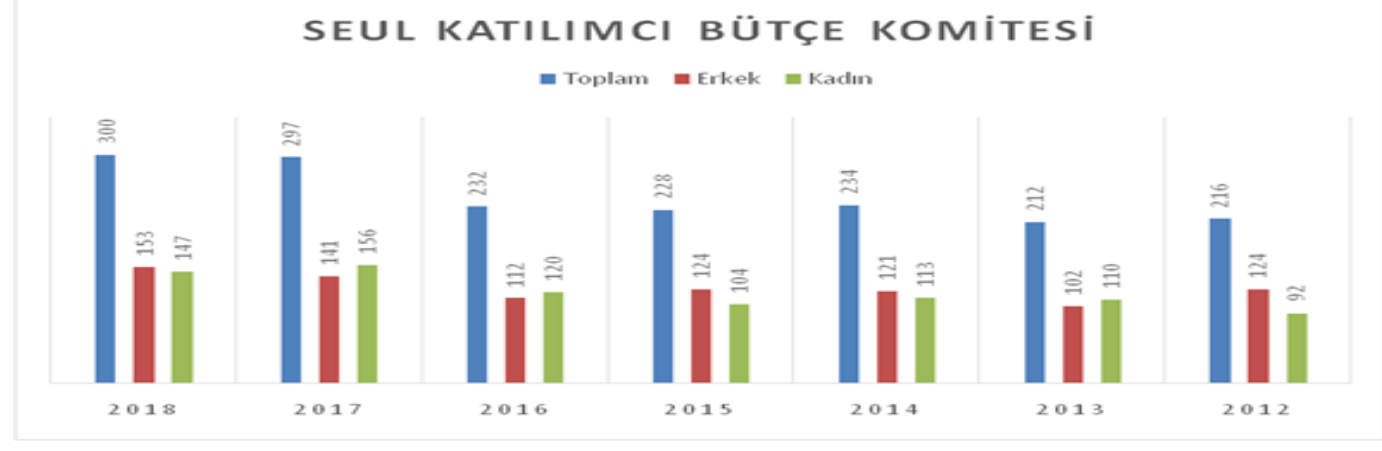

Kaynak: Seul Metropolitan Government 
Başvuru yapan vatandaşlar arasından belirlenen üyeler bir dönem için görev yapmaktadırlar. Görev süresini en fazla bir dönem daha uzatmak mümkündür. Çekiliş yapılırken yöntem olarak Cinsiyet, yaş ve bölgesel dengeler dikkate alınarak elektronik çekiliş yapılmaktadır. Şekil 3'te görüleceği üzere 2018 yılında bütçe komitesinin 300 üyesinin 153'ü erkek, 147'si kadındır. 2017 ve 2016 yılında ise kadın üye sayısının erkek üye sayısından daha fazla olduğu görülmektedir. Temsilde cinsiyet eşitliğine özel bir önem verilmektedir.

b. Özel-Kamu Bütçe Destek Komitesi: Bu komite, konularına göre sınıflandırılan katılımcı bütçe projelerini değerlendiren komitedir. Komitede maksimum üye sayısı, alan başına 27 olarak belirlenmiştir. Katılımcı Bütçe Komite üyeleri, konularında uzman özel sektör ve kamu sektörü ve sivil kuruluşlardaki kişilerden oluşmaktadır. Destek komitelerinin en az 2/3'ü Katılımcı Bütçe Komitesi Üyelerinden oluşmaktadır. Bu komite 2018 yılında Seul 'de 10 bölgede kurulmuştur.

c. Katılımcı Bütçe Destek Komitesi: Bu komite, vatandaşların katılımcı bütçe konusunda eğitilmesi, farkındalık yaratılması, sistemin işleyişi konusunda ortaya çıkan sorunlarda danışmanlık yapmak, iyileştirmeler ve önlemler alınmasını sağlamak amacıyla kurulmuştur. Bu komitenin oluşumunda en fazla 30 belediye meclisi üyesi, bütçe uzmani, sivil toplum kuruluşları temsilcisi, bütçe komitesi üyesi ve konuyla ilgili memurlar yer almaktadır. Memurların oranı komitenin yüzde ellisinden az olmak zorundadır. 2018 yılındaki oluşuma baktığımızda, 1 belediye meclisi üyesi, 10 uzman ve sivil toplum kuruluşu üyesi, 16 Katılımcı Bütçe Komitesi üyesi ve 3 sivil görevli katılımcı bütçe destek komitesinde yer almıştır

\section{Sonuç}

Bu çalışmada katılımcı bütçe uygulama örneklerinden Porto Alegre, Paris ve Seul deneyimleri ele alınmıştır. Porto Alegre katılımcı bütçenin ilk uygulandığı yer olması nedeniyle diğer uygulamaların esin kaynağı olmuştur. Çalışmada ele alınan üç kent nüfus ölçeği açısından değerlendirildiğinde, Porto Alegre küçük, Paris orta, Seul ise büyük kent ölçeklerinde katılımc1 bütçe uygulamasına örnek teşkil etmektedir. Farklı ölçekteki üç örnek, yer yer benzerlikler göstermesine karşın ülkelerin kendi sosyal, ekonomik, kültürel yapılarından etkilendikleri gözlemlenmektedir. Porto Alegre, doğrudan temsil sürecini mahallelerden başlayarak uygulamaktadır. Paris daha çok dinamik ve örgütlenmiş sivil toplum ve ana temalara göre oluşturulmuş kent meclislerini süreç içerisinde daha aktif hale getirmiştir. Seul, 10 milyonu aşan nüfusu ile katılımcı bütçe uygulamalarının büyük bir ölçekte uygulanmasının başarılı örneklerinden birini oluşturmaktadır.

Tüm uygulamaların ortak noktası, karar sürecine vatandaş ve sivil toplum kuruluşlarının dahil edilmesi ve bütçenin belirli bir kısmının nereye harcanacağı konusunda ortak karar verilmesidir. $\mathrm{Bu}$ uygulamadan beklenen fayda ise katılımcı demokrasiyi geliştirmek, bütçe kaynaklarının tahsisatını iyileştirmek, ekonomik istikrara katkı yapmak ve gelir dağılımını iyileştirmektir.

Porto Alegre katılımcı bütçesi, yoksulluk, konut üretimi, sağlık bakımı, suç oranını düşürme, okul koşullarının iyileştirilmesi, altyapı hizmetleri gibi alanlarda iyileşmeler sağlamıştır. Paris örneğinde ise katılımcı demokratik mekanizmaların işletilmesi, siyasi hoşnutsuzlukların azaltılması, siyasal sisteme olan güveni artırmak, şeffaflık, temsili demokrasinin aksaklıklarını gidermek, Paris'li olmak ve aidiyet duygusunu sağlamak hedefleri ön plana çıkmaktadır. Seul katılımcı bütçesi ise daha çok mevcut hükümet politikası vaatleri çerçevesinde şekillenmiştir. Yerel yönetimlerde vatandaşların bütçe karar alma sürecine katılmalarına izin vermesinin önünü açan "Yerel Finans Yasasını" yeniden düzenlenmesi sonrası gelişmeler kaydedilmiştir. Seul, katılımcı bütçeyi nüfusu 10 milyonun üzerinde olan şehirlerden ilk uygulayan şehir olmuştur.

Katılımcı bütçe, kentler için alternatif bir bütçe sunumu ile hızlı büyümesine devam etmektedir. Özellikle vatandaş katılımını ve demokratik yenilemeyi teşvik etmesi nedeniyle ilgi 
görmeye devam etmektedir. Demokratikleşmenin toplumun tamamını dönüştürmek için kapsayıcı olması ve araç- gereç ve mekanizmaların bir kombinasyonunu içermesi gerekmektedir. Bu anlamda katılımcı bütçeleme alternatifler sunmaktadır. Dünya deneyimleri, kent yaşamının çeşitli yönleriyle ilgili birçok vatandaş toplantısı, çalıştay ve istişare toplantısı düzenlenmesinin kente aidiyet duygusunu artırıyor olduğunu göstermektedir. Katılımcı bir şekilde bütçenin tasarlanması ise bugüne kadar hâkim paradigma olan yukarıdan aşağıya bütçenin sunulması anlayışında ciddi değişimler yaratmaktadır. Vatandaş ve seçilmişler arasında daha fazla iş birliği ve daha fazla güvence verilmesi beraberinde şeffaflık sağlama yönünde önemli katkılar yapmaktadır.

Çalışmamızda incelenen Paris ve Seul örnekleri de göstermektedir ki artık katılımcı bütçe süreçleri sadece küçük yerleşim yerlerine özgü bir katılımcı araç olmaktan çıkmıştır. Dünyanın büyük metropollerinden olan Seul ve Paris bu çalışmamızın kapsamına girmeyen New York, Madrid gibi önemli örnekler bunlara örnek verilebilir. Ülkemizde İstanbul, Ankara, İzmir, Bursa, Adana gibi kentlerimiz katılımcı bütçeleme süreçlerini gündemlerine almalıdır. Bunun için öncelikle yasal bir düzenlemenin yapılması yerinde olacaktır. Çalışmamız kapsamında ele alınan kent örnekleri katılımcı bütçe sürecinin kent nüfusu arttıkça farklılıklar arz ettiğini göstermektedir. Küçük yerleşim yerlerinden doğrudan temsil ve katılım olanağı daha yüksek iken nüfus ölçeği arttıkça komiteler ve oluşturulan konseyler aracılığı vatandaş temsili ve katılımı sağlanmaktadır. Bu anlamda Kent Konseylerinin yapısında yapılacak değişikliklerle katılımcı bütçeleme sürecinde daha aktif alması rol mümkündür.

\section{Kaynakça}

Bahçeci, D (2009) Belediyelerde katılımc1 bütçe süreci, Yeşil Gazete, https://yesilgazete.org/blog/2009/02/20/belediyelerde-katilimci-butce-sureci/ (Erişim tarihi: 05.08.2019).

Baiocchi, G. (2003) Radicals in power: the Workers' Party (PT) and experiments in urban democracy in Brazil. London: ZedBooks.

Baiocchi, G. (2005) Militants and citizens: The politics of participatory democracy in Porto Alegre: Stanford UniversityPress.

Budgetparticipatif.paris (2019) https://budgetparticipatif.paris.fr / (Erişim tarihi: 02.04.2019).

Cabannes, Y. (2004) Participatory budgeting: a significant contribution to participatory democracy. Environment and Urbanization, 16(1), 27-46. https://journals.sagepub.com/doi/pdf/10.1177/095624780401600104 (Erişim tarihi: 26.02.2019).

Carlson, J. (2017). Expanding the imagination of democracy: PB in Paris, https://www.participatorybudgeting.org/pbparis/ (Erişim tarihi: 20.02.2019).

Çelebi, A (2012) Porto Allegre gezi notları. http://www.celebialper.com/ulkeler/brezilya/portoalegrede-mimari-ve-sanat.html (Erişim tarihi: 25-02-2019).

Cho, S. \& Mor B.M.E. (2008) Understanding of diversity and inclusion in a perceived homogeneous culture: a study of organizational commitmentand job performance Among Korean employees. Administration in Social Work, 32(4), 100-126. https://www.tandfonline.com/doi/abs/10.1080/03643100802293865 (Erişim tarihi: 22.02.2019).

Gürcan E.C. (2011). 1791 ve 1793 Fransız Anayasaları'na ilişkin karşılaştırmalı bir Değerlendirme, Gazi Üniversitesi İktisadi ve İdari Bilimler Fakültesi Dergisi, 13(3), 183-214.

Fölscher, A (2007), Participatory budgeting in central and Eastern Europa in Participatory Budgeting, Anwar Shah (Ed.), The World Bank Washington D.C.: The World Bank-The Public Sector Governance and Accountability Series, 2007. 
Goldfrank, B (2006). Lessons from Latin American experience in participatory budgeting. https://www.researchgate.net/publication/253455515_Lessons_from_Latin_American_Exper ience_in_Participatory_Budgeting (Erişim tarihi: 22.02.2019).

Goldsmith,W.W. \& Vainer,B.C (2001) Participatory budgeting and power politics in Porto Alegre, Lincoln Institute Land Lines Journal, October 2001, https://www.lincolninst.edu/publications/articles/participatory-budgeting-power-politicsporto-alegre (Erişim tarihi: 28.02.2019).

Marion, G.\&Yves, S. (2005). The Porto Alegre Experiment: Learning Lessons for Better Democracy. London: ZedBooks.

Lee, J.W. (2000) A casestudy on the budget preparation process in local government system, Korean Public Administration Review, 33(4), 153-168.

Marquetti, A. \& Silva, C. E. \& Campbell, A. (2012). Participatory economic democracy in action: participatory budgeting in Porto Alegre, 1989-2004. Review of Radical Political Economics. 44(1), 62-81.

Medenian, H Scully, P.L. (2018) Participatory budgeting in Paris, France https://participedia.net/en/cases/participatory-budgeting-paris-france (Erişim tarihi: 26.02.2019)

Mitchell, S.W. (2014) An Exploratory Study of Priority Based Budgeting: Identification of Public Values and Public Priorities through Citizen Engagement in Government Budgeting Decisions (Doctoral thesis). Lawrence Technological University College of Management.

Moynihan, D. P. (2007). Citizen participation in budgeting: Prospects for developing countries. Participatory budgeting, 55-87. https://siteresources.worldbank.org/PSGLP/Resources/ParticipatoryBudgeting.pdf (Erişim tarihi: 20.02.2019).

Nelson D. (ed), (2014) Hope for Democracy - 25 Years of Participatory budgeting worldwide ,Loco Association http://www.in-loco.pt/upload_folder/edicoes/1279dd27-d1b140c9-ac77c75f31f82ba2.pdf (Erişim tarihi: 15.02.2019).

Napolitano, A. (2015) Report on Paris: largest participatory budget in Europe, https://pbnetworkorg.uk/report-on-paris-largest-participatory-budget-in-europe/ (Erişim tarihi: 20.02.2019).

Sahah, A. (2007) Participatory budgeting, Word Bank, public sector governance and accountability series, https://siteresources.worldbank.org/PSGLP/Resources/ParticipatoryBudgeting.pdf (Erişim tarihi: 22.02.2019).

Sakınç, S. \& Bursalığlu, S. A. (2014). Bütçelemede demokratik bir değişim: Katılımcı bütçeleme. Electronic Journal of Vocational Colleges, 4(1), 1-10.

Seul Metropolitan Government (2019) http://english.seoul.go.kr/get-to-know-us/cityhall/budget/participatory-budget-system/ (Erişim tarihi: 02.04.2019).

Sintomer, Y\& Herzberg, C \& Röcke, A., \& Allegretti, G. (2012). Transnational models of citizen participation: the case of participatory budgeting. Journal of Public Deliberation, 8(2), Article-9.

Smith, G. \& Fletcher, S. (2017). Participatory budgeting: Porto Alegre 2005-2007 https://www.participedia.net/en/cases/participatory-budgeting-porto-alegre\#cite_note-two-1, (Erişim tarihi: 21.02.2019). 
Sobacı, M.Z. \& Köseoğlu, Ö. (2016). Başkanlık sistemlerinde yerel yönetimler ABD, Brezilya, Şili, Endonezya ve Güney Kore, SETA Siyaset, Ekonomi ve Toplum Araştırmaları Vakfi http://file.setav.org/Files/Pdf/20160517121509_basskanlik-sistemlerindeyerel-yoonetimlerpdf.pdf_(Erişim tarihi: 25-02-2019).

Sousa S. B. (1998). Participatory budgeting in Porto Alegre: toward a redistributive democracy. Politics \& Society, 26(4), 461-510.

Tekeli, İ. (2004), Katılımcı demokrasi, sivil ağlar ve sivil toplum kuruluşları. 15. Sivil Toplum Kuruluşları Sempozyumu,İstanbul 1-13.

Tobin I. \&Hyunkuk L.\&Wonhyuk C. \&Jesse W. C. (2014) Citizen preference and resource allocation: The case for participatory budgeting in Seoul, Local Government Studies, 40(1), 102-120,

UN-Habitat (2004). 72 Fruquently asked questions about participatory budgeting, Urban Governance Toolkit Series. https://unhabitat.org/books/72-frequently-asked-questions-aboutparticipatory-budgeting/_(Erişim tarihi: 26.02.2019).

Wampler, B.\&McNulty S. \&Touchton, M. (2017) Participatory budgeting: spreading across the globe, Open Goverment web site 13 October 2017 https://www.opengovpartnership.org/stories?page=42, (Erişim tarihi: 18-02-2019).

Wampler, B. (2007). A Guide to participatory budgeting, in Ed. A. Shah, Participatory budgeting, Washington, D.C.

Wampler, B. (2000). A guide to participatory budgeting. http://www.internationalbudget.org/wpcontent/uploads/A-Guide-to-Participatory-Budgets.pdf (Erişim tarihi: 25.02.2019).

Yalçın, A.Z, (2015). Yerel yönetimlerde katılımcı bütçeleme, Celal Bayar Üniversitesi Yönetim ve Ekonomi Dergisi, 22(2), 311- 329.

\section{ETIKK ve BİLIMSEL İLKELER SORUMLULUK BEYANI}

$\mathrm{Bu}$ çalışmanın tüm hazırlanma süreçlerinde etik kurallara ve bilimsel atıf gösterme ilkelerine riayet edildiğini yazar(lar) beyan eder. Aksi bir durumun tespiti halinde Afyon Kocatepe Üniversitesi Sosyal Bilimler Dergisi'nin hiçbir sorumluluğu olmayıp, tüm sorumluluk makale yazarlarına aittir. 